\title{
Kultura fizyczna a kultura - rozważania teoretyczne
}

\section{Physical culture and culture - theoretical considerations}

\section{Streszczenie:}

Celem artykułu jest analiza terminu kultura fizyczna jako istotnego elementu szerszej kultury. W polskim piśmiennictwie naukowym pojęcie to nie zawsze jest rozpatrywane $\mathrm{z}$ perspektywy jego związków z ogólną kulturą, pojawiają się wręcz opinie, iż nie należy zaliczać go do kultury. Główną tezę artykułu stanowi stwierdzenie, iż kultura fizyczna stanowi część ogólnej kultury i w oparciu o nią powinna być rozpatrywana. Podjęta zostanie także próba odpowiedzi na pytanie dotyczące powodów braku zgody odnośnie tak fundamentalnego zagadnienia, jak związek pomiędzy kulturą fizyczną a kulturą.

Słowa kluczowe: kultura fizyczna, kultura, teoria kultury

\begin{abstract}
:
The aim of the article is to analyze the term physical culture as an important element of culture in general. In Polish scientific literature the term is not always considered from the perspective of its association with culture. There are even views that it should not be regarded as a part of it. According to the main hypothesis, physical culture is an element of culture in general. An attempt to answer the question about the reasons for lack of consensus
\end{abstract}


Michał Marcin Kobierecki - Kultura fizyczna a kultura...

concerning such a fundamental issue as the association between culture and physical culture will also be conducted.

Keywords: physical culture, culture, theory of culture

\section{Wstęp}

Niemal każdy człowiek ma w swoim życiu do czynienia z kulturą fizyczną - uprawiając sport lub turystykę, uczęszczając na zajęcia wychowania fizycznego w szkole, aktywnie wypoczywając itp. Celem niniejszego artykułu jest analiza terminu kultura fizyczna jako istotnego elementu szerszej kultury. Teza taka wydaje się być oczywista, jednak w polskim piśmiennictwie naukowym pojęcie to nie zawsze było rozpatrywane z perspektywy jego związków z ogólną kulturą, przynajmniej w wymiarze funkcjonalnym. Co prawda znawcy tematu zdają się potwierdzać wspomnianą relację pomiędzy kulturą a zawierającą się w niej kulturą fizyczną, jednak zagadnienie to nie jest jednoznaczne.

Pierwsza część artykułu dotyczy ogólnych rozważań na temat znaczenia pojęcia kultura fizyczna. Wprowadzone zostaną definicje prezentujące różne ujęcia tego terminu oraz opisane zostaną krótko jego elementy składowe, a także przybliżone zostanie zagadnienie związane z pojawiającą się niekiedy krytyką jego stosowania, co ma związek z ideologicznym wykorzystywaniem kultury fizycznej w okresie funkcjonowania rządów komunistycznych w państwach Europy Środkowej i Wschodniej, w tym także i w Polsce. Natomiast druga część pracy dotyczyć będzie głównej tematyki podjętej w artykule, mianowicie miejsca kultury fizycznej w ogólnej kulturze. Przedstawione zostaną zatem dominujące stanowiska $\mathrm{w}$ tej materii, prezentowane przez teoretyków kultury fizycznej.

Główną tezę artykułu stanowi stwierdzenie, iż kultura fizyczna stanowi część ogólnej kultury i w oparciu o nią powinna być rozpatrywana. W ramach dywagacji podjęta zostanie także próba odpowiedzi 
na pytanie badawcze dotyczące powodów braku zgody odnośnie tak fundamentalnego zagadnienia, jak związek pomiędzy kulturą fizyczną a kulturą.

Badania podjęte $\mathrm{w}$ artykule zostały przeprowadzone $\mathrm{z}$ wykorzystaniem metody hermeneutycznej oraz komparatystycznej. Analiza wymagała bowiem wyjaśnienia kontekstu znaczeniowego pojęcia kultura fizyczna, a po części także terminu kultura. Okazały się one niejednoznaczne, konieczne było zatem przyjrzenie się szeregowi ujęć, jakie są im przypisywane przez czołowych naukowców zajmujących się daną tematyką.

\section{O pojęciu kultura fizyczna}

Kultura fizyczna jest pojęciem bardzo dokładnie wytłumaczonym i zdefiniowanym $\mathrm{w}$ piśmiennictwie naukowym. Mimo to można powiedzieć o nim, iż nie jest rozumiane w sposób jednoznaczny. Można w związku z tym wskazać na cały szereg definicji prezentowanych przez jej teoretyków. Jako sformułowanie słowne zestawiane jest z kilkoma innymi określeniami, takimi mianowicie jak: kultura somatyczna czy kultura cielesna, które jednak nie są z nią w pełni tożsame. Pojęcie kultura fizyczna można ujmować jako formę świadomości społecznej - w tym sensie jest ona jednym z symboliczno-kulturowych typów praktyki społecznej. W oparciu o opcję utrzymaną w duchu socjobehawioryzmu i w nawiązaniu do antropologicznej koncepcję kultury Antoniny Kłoskowskiej, definicję kultury fizycznej zaproponował Zbigniew Krawczyk, według którego jest to względnie zintegrowany i utrwalony system zachowań w dziedzinie dbałości o rozwój fizyczny, sprawność ruchowq, zdrowie, urodę, fizycznq doskonałość i ekspresję człowieka, przebiegających według przyjętych $w$ danej zbiorowości wzorów, a także rezultaty owych zachowań1. Kulturę fizyczną można

1 Z. Krawczyk, Od aksjologii ciała do koncepcji kultury fizycznej, [w:] Kultura fizyczna i sport w ujęciu socjologicznym. Wybór tekstów, H. Sekuła-Kwaśniewicz (red.), Kraków 1985, s. 46. 
Michał Marcin Kobierecki - Kultura fizyczna a kultura...

również rozpatrywać w ujęciu holistycznym. W tej perspektywie Jerzy Kosiewicz określił ją jako zespół form świadomości społecznej, które integrujq i utrwalajq zwiq̨zek wiedzy oraz zachowań stanowiq̨cych podstawę dla harmonijnego rozwoju wszechstronnej, dojrzałej osobowości i zdrowia w płaszczyźnie fizycznej, psychicznej i relacyjnej. Wreszcie, kultura fizyczna może być rozpatrywana w porównaniu z kulturą somatyczną - traktując te dwa terminy jako tożsame².

Z pewnością warte przytoczenia jest ujęcie zawarte w polskiej Ustawie o kulturze fizycznej z 1996 r. Kulturę fizyczną zdefiniowano w tym akcie jako wiedza, wartości, zwyczaje, działania podejmowane dla zapewnienia rozwoju psychofizycznego, wychowania, doskonalenia uzdolnień i sprawności fizycznej człowieka, a także dla zachowania i przywracania jego zdrowia ${ }^{3}$. Jest to zatem definicja zbliżona nieco do prezentowanego wyżej ujęcia socjobehawioralnego, zwracająca uwagę na zagadnienia prozdrowotne oraz zmierzające do powiększania sprawności fizycznej.

Nawiązując do polskiego piśmiennictwa dotyczącego kultury fizycznej, należy zwrócić uwagę także na inne rozróżnienie jeśli chodzi o koncepcje, zgodnie z którymi interpretuje się to pojęcie. Należą do nich: indywidualistyczno-wartościująca, socjologizująco-uniwersalistyczna i holistyczna. Pierwsza z nich jest jednak na ogół krytykowana za zbyt wąską interpretację słowa kultura. Zgodnie z koncepcją socjologizująco-uniwersalistyczną kulturę fizyczną postrzega się jako zjawisko o charakterze grupowym, obejmujące zarówno zachowania zwiq̨zane z dbałościq o rozwój fizyczny, sprawność ruchowa, zdrowie i piękno człowieka, jak i rezultaty tych zachowań. W ujęciu holistycznym natomiast kultura fizyczna to obiekt zewnętrzny wobec człowieka, będacy czynnikiem wyznaczającym na podstawie przyjętych $w$ danej zbiorowości systemów wartości określone schematy postępowania ${ }^{4}$.

\footnotetext{
2 J. Kosiewicz, Kultura fizyczna i sport w perspektywie filozofii, Warszawa 2000, s. $17-25$.

${ }^{3}$ Ustawa o kulturze fizycznej z dnia 18 stycznia 1996 r., Dz. U. Nr 25, poz. 113.

${ }^{4} \mathrm{M}$. Marcinkowski, M. Sokołowski, Aksjologiczne i funkcjonalne aspekty kultury fizycznej w wojsku, t. VII, Warszawa 2004, s. 47.
} 
Obok kultury fizycznej wyróżnia się niekiedy pojęcie body culture, które uznaje się za szersze od niego jeśli chodzi o zakres. Obejmuje ono wszystkie sportowe i pozasportowe zjawiska, zabiegi, teorie oraz refleksje naukowe i pozanaukowe odnoszące się do uwarunkowanych kulturowo aspektów ludzkiego ciała. Za odpowiednik body culture uznaje się pojęcie kultury somatycznej5.

Powyżej wskazano jedynie niektóre definicje kultury fizycznej prezentowane przez polskich teoretyków tej sfery rzeczywistości. Jak widać, kulturę fizyczną można rozumieć na wiele sposobów, akcentowane są ponadtoróżne jej elementy. Z całą pewnością można jednak stwierdzić, iż jako kategoria kultura fizyczna obejmuje liczne aspekty związane z ruchem i dbaniem o ciało.

\section{Kultura fizyczna i jej elementy składowe}

Jak widać z przytoczonych wyżej definicji kultury fizycznej, jest to pojęcie rozumiane na szereg sposobów, mniej lub bardziej zbliżonych do siebie. Kultura fizyczna bywa jednak tłumaczona także w sposób addytywny, a zatem poprzez wyliczenie jej elementów składowych, mimo że niektórzy badacze krytykują taki sposób ujmowania tej kategorii twierdząc, iż nie można do kultury fizycznej czegoś włączyć bądź czegoś z niej wykluczyć́. Jak można by się spodziewać biorąc pod uwagę różne sposoby definiowania tego terminu, nie ma także zgody jeśli chodzi o przedziały rzeczywistości, które można zaliczyć jako jej elementy składowe. W związku z tym różni badacze wskazują na różne nieco zakresy pojęcia kultura fizyczna. Poniżej przedstawione zostaną kluczowe stanowiska w tej kwestii.

5 J. Kosiewicz, Sport w perspektywie filozofii, [w:] Nauki społeczne wobec sportu współczesnego, J. Kosiewicz, P. Bany, M. Piątkowska, J. Żyśko (red.), Warszawa 2010, s. 37-38. Por.: H. Eichberg, Body Culture. Essays on sport, space and identity, J. Bale, C. Philo (red.), London 1998.

${ }^{6}$ B. Szczechowicz, Kultura fizyczna jako źródło wartości produktu turystycznego, Warszawa 2012, s. 15. 
Michał Marcin Kobierecki - Kultura fizyczna a kultura...

W nawiązaniu do powyższego, kulturę fizyczną można definiować szeroko lub wąsko. W ujęciu szerokim termin ten obejmuje wychowanie fizyczne, sport, rekreację ruchową i rehabilitację, a także turystykę, natomiast $\mathrm{w}$ wąskim zakres ten nie uwzględnia turystyki ${ }^{7}$. $\mathrm{Na}$ właśnie takie elementy składowe kultury fizyczne zwrócił uwagę Zbigniew Krawczyk, uszczegółowiając je nieco. Wymienił on bowiem następujące komponenty kultury fizycznej (rozumianej jako całość): wychowanie fizyczne (szkolne, dzieci i młodzieży), sport (dla wszystkich, wyczynowy), rekreacja fizyczna (dorosłych i w wieku poprodukcyjnym) i rehabilitacja ruchowa. Jak stwierdził ów autor w odniesieniu do ewentualnego zaliczania turystyki do kultury fizycznej, uzależnione jest to od tego, czy instytucje państwowe zarządzające turystyką w danym kraju są zintegrowane z instytucjami odpowiedzialnymi za inne sfery kultury fizycznej ${ }^{8}$.

Ujęcie addytywnej definicji kultury fizycznej zaprezentował także Jerzy Kosiewicz, według którego do kultury fizycznej zaliczyć można sport wyczynowy, sport masowy, sport powszechny, sport amatorski, sport szkolny, sport osób niepełnosprawnych, wychowanie fizyczne, gry i zabawy, rekreację ruchową, turystykę wyczynową, turystykę pątniczą oraz rekreacyjne formy turystyki ${ }^{9}$. Jak widać ponadto, powyższe rozróżnienie także jest dalece bardziej uszczegółowione w porównaniu z najbardziej popularnym rozróżnieniem.

Na uwagę zasługuje przy tym fakt, iż w powyższej definicji nie została uwzględniona rehabilitacja. Jest to kolejny, obok turystyki komponent, który nie zawsze jest brany pod uwagę jako część składowa pojęcia kultura fizyczna. Zdaniem Bogdana Kunickiego, w kulturze fizycznej wyróżnia się trzy główne, przenikające się silnie segmenty, mianowicie sport, wychowanie fizyczne i rekreację, natomiast wielu

\footnotetext{
7 A. Nowakowski, Zarządzanie kultura fizyczna w Polsce w latach 1944-2001. Studium historyczno-porównawcze, Rzeszów 2005, s. 13.

8 Z. Krawczyk, O kulturze fizycznej. Studia i szkice, Warszawa 1983, s. 13. Por.: B. Ryby, Kultura fizyczna - ważna dziedzina życia społecznego, [w:] Księga sportu polskiego 1944-1974, J. Rajkowska (red.), Warszawa 1975, s. 9.

9 J. Kosiewicz, Sport w perspektywie..., op. cit., s. 29.
} 
autorów dodaje do tego również turystykę i rehabilitację ruchową. Co do tych dwóch ostatnich elementów w środowisku naukowym nie ma jednak zgody ${ }^{10}$. Co więcej, w Ustawie o sporcie z dn. 25.06.2010 r. stwierdzono, iż sport wraz z wychowaniem fizycznym i rehabilitacjq ruchowq składajq się na kulture fizyczną ${ }^{11}$, Zatem polski ustawodawca także zaliczył do kultury fizycznej trzy elementy, przy czym zamiast rekreacji fizycznej uwzględniona została rehabilitacja ruchowa. W niniejszym artykule przyjęte zostanie jednak w nawiązaniu do piśmiennictwa naukowego, iż to sport, wychowanie fizyczne i rekreacja fizyczna należą do form uczestnictwa w kulturze fizycznej, co do których panuje względna zgoda.

Konkludując powyższe rozważania, na kulturę fizyczną składają się takie elementy, jak sport, wychowanie fizyczne oraz rekreacja fizyczna, a także w zależności od przyjętej orientacji, także rehabilitacja oraz turystyka. W poszukiwaniu znaczenia pojęcia kultura fizyczna zasadnym wydaje się zatem krótki przegląd znaczeń poszczególnych jej komponentów. Zadanie to nie jest łatwe ze względu na zróżnicowane rozumienia także i tych terminów. W związku z tym przytoczone zostaną jedynie wybrane objaśnienia poszczególnych komponentów kultury fizycznej.

Sport rozumieć można jako kreatywnq, świadomq i dobrowolnq działalność fizycznq, będq̨cq wyspecjalizowanq grą, której celem jest dqzżenie do jak najdoskonalszych wyników oraz wszechstronnego rozwoju człowieka. Istota owej działalności jest współzawodnictwo i rywalizacja, które maja nieantagonistyczny charakter i odbywają się zgodnie z przyjętymi regułami, $w$ tym także z normami prawnymi. Sport od innych przejawów dobrowolnej aktywności fizycznej odróżnia stabilność instytucjonalna, powszechność oraz konieczność wykorzystywania specjalistycznych obiektów i sprzętu. Na poziomie zawodowym sport

10 B. J. Kunicki, Społeczeństwo, kultura, kultura fizyczna, [w:] Socjologia kultury fizycznej, Z. Dziubiński, Z. Krawczyk (red.), Warszawa 2011, s. 59-60.

11 Ustawa z dnia 25 czerwca 2010 o sporcie, Dz. U. z 2010 r. Nr 127, s. 1. 
Michał Marcin Kobierecki - Kultura fizyczna a kultura...

może mieć charakter pracy ${ }^{12}$. Niekiedy rozróżnia się ponadto sport wyczynowy (kwalifikowany), masowy (powszechny), amatorski, zawodowy itp. W niniejszym artykule nie ma miejsca na rozwijanie tego zagadnienia. Należy zatem przyjąć, iż sport stanowi najbardziej wyspecjalizowaną formę kultury fizycznej, a charakteryzuje go ukierunkowanie na rywalizację i zwyciężanie. Sport cieszy się niezwykłą popularnością, a największe wydarzenia sportowe przyciągają przed ekrany telewizorów wiele milionów widzów. W związku z tym rozpatrywany jest niekiedy jako element kultury masowej, o czym więcej w dalszej części artykułu.

Zupełnie odmienny charakter można przypisać rekreacji fizycznej, przy opisywaniu której przede wszystkim zwraca się uwagę na jej opozycję wobec pracy ${ }^{13}$ oraz wykonywanie jej "dla samego wykonywania", nie zaś dla jakiegoś głębszego celu14. Istotny jest tu także element odpoczynku jako jedna z głównych korzyści związanych z rekreacją fizyczną ${ }^{15}$. Termin ten można zatem zdefiniować za Teresą Wolańską jako wszystkie zajęcia o treści ruchowo-sportowej lub turystycznej, którym człowiek oddaje się z własnych chęci w czasie wolnym od obowiq̨zków, dla wypoczynku, rozrywki i dla rozwoju własnej osobowości ${ }^{16}$. Spośród wszystkich form uczestnictwa w kulturze fizycznej rekreacja ma z całą pewnością najbardziej autoteliczny charakter, podczas gdy za jej przeciwieństwo pod tym względem można by uznać sport, w szczególności w jego elitarnej odmianie.

Trzecim z kluczowych komponentów kultury fizycznej jest wychowanie fizyczne. Za Zbigniewem Krawczykiem można je wyjaśnić

12 M. M. Kobierecki, Czym jest sport? Analiza wybranych definicji pojęcia „sport” oraz pojęć zbliżonych, [w:] Z dziejów kultury fizycznej Polski oraz wybranych regionów i mniejszości narodowych, J. Dżereń (red.), Płock 2011, s. 232.

13 Por. J. Kosiewicz, Free Time and Freedom of Choice, [w:] Movement Recreation for All, J. Kosiewicz (red.), Legionowo 2006, s. 15-22, Idem, Spór o istnienie i wolność wyboru, [w:] Sport jako kulturowa rzeczywistość, Z. Dziubiński (red.), Warszawa 2005, s. 61-69.

${ }^{14}$ L. Haywood et al., Understanding Leisure, Cheltenham 2002, s. 3-4. s. 192.

15 J. Kosiewicz, Sport and Philosophy. From Methodology to Ethics, Warszawa 2009,

16 T. Wolańska, Rekreacja fizyczna, Warszawa 1971, s. 11. 
jako wprowadzenie człowieka w świat kultury fizycznej oraz kreacja jego ciała zgodnie z przyjętymi $w$ danym społeczeństwie wzorami i ideałami wychowawczymi ${ }^{17}$. Jest to bardzo ogólne rozumienie, jednak wydaje się zarazem trafne. W potocznym znaczeniu wychowanie fizyczne kojarzy się na ogół z lekcjami „WF-u” w szkołach, których celem jest poprawa i kształtowanie sprawności fizycznej wśród młodzieży. W definiowaniu wychowania fizycznego zwraca się uwagę na jego podwójną rolę - zaspokajanie doraźnych potrzeb jeśli chodzi o fizyczny rozwój oraz przygotowanie do dbałości o ciało po zakończeniu procesu wychowawczego. Zdaniem Henryka Grabowskiego wychowanie fizyczne stanowi ponadto fundament kultury fizycznej, gdyż to właśnie od niego zależy poziom innych form uczestnictwa w niejej.

Wśród teoretyków kultury fizycznej istnieje zgoda co do tego, iż trzy powyższe komponenty: sport, rekreacja fizyczna i wychowanie fizyczne składają się na pojęcie kultury fizycznej. Jak wspomniano, nie ma zgody odnośnie tego, czy rehabilitację i turystykę także należałoby uznać za jej komponenty. Dla dopełnienia rozważań stwierdzić trzeba, iż rehabilitacja ruchowa (cielesna) oznacza system normatywnie uregulowanych czynności stosowany w znoszeniu problemów osoby wykluczonej z kultury społecznej w następstwie utraty sprawności ${ }^{19}$, podczas gdy turystyka dotyczy pobytu poza miejscem i środowiskiem stałego zamieszkania, podczas którego turysta koncentruje się na „pokonywaniu trasy i delektowaniu się przebiegiem tej akcji ${ }^{20}$.

\section{Ideologiczny wydźwięk pojęcia kultura fizyczna}

Opisywane powyżej pojęcie kultury fizycznej jest niekiedy postrzegane w sposób pejoratywny, a to za sprawą wykorzystywania go

\footnotetext{
17 Z. Krawczyk, O kulturze fizycznej..., op. cit., s. 21.

${ }^{18}$ H. Grabowski, Wychowanie fizyczne, [w:] Kultura fizyczna. Sport. Encyklopedia kultury polskiej XX wieku, Z. Krawczyk (red.), Warszawa 1997, s. 45.

19 A. Pawłucki, Naukowa legitymizacja rehabilitacji cielesnej, [w:] „Rozprawy Naukowe Akademii Wychowania Fizycznego we Wrocławiu" 2012, nr 39, s. 4.

20 B. Szczechowicz, Kultura fizyczna jako..., op. cit., s. 18, 23.
} 
w celach ideologicznych przez władze w czasach Polskiej Rzeczpospolitej Ludowej. Co ciekawe, chociażby w Stanach Zjednoczonych pojęcie to jest mało znane i właściwie nie używane, w przeciwieństwie do Kanady, Wielkiej Brytanii, Francji, Niemiec, państw skandynawskich oraz w szczególności państw Europy Środkowej i Wschodniej oraz Rosji21. Popularność sformułowania kultura fizyczna między innymi w naszym kraju wynika po części przynajmniej właśnie z jego znaczenia ideologicznego w okresie zimnej wojny.

Od początku istnienia PRL deprecjonowano częściej wykorzystywane uprzednio pojęcia jak wychowanie fizyczne i sport na rzecz właśnie kultury fizycznej ${ }^{22}$. Właśnie w okresie istnienia Polski Rzeczpospolitej Ludowej wystąpiła tendencja, co odzwierciedlone zostało w oficjalnej i naukowej nomenklaturze, do częstego posługiwania się pojęciem kultura fizyczna jako poniekąd synonimu terminów sport oraz wychowanie fizyczne. Jak wynika z rozważań podjętych we wcześniejszych fragmentach artykułu, jest to oczywiście błędne, ponieważ kultura fizyczna jest terminem o znacznie szerszym zakresie, integrującym zarówno sport i wychowanie fizyczne, jak i szereg innych komponentów. Lektura literatury z początku lat pięćdziesiątych wydaje się jednak potwierdzać powyższe stwierdzenie odnośnie takiego właśnie ujmowania znaczenia kultury fizycznej. Nie można oczywiście stwierdzić, iż słowo sport zostało wyparte przez sformułowanie kultura fizyczna. Niejednokrotnie obydwa pojęcia były stosowane wspólnie np. jako kultura fizyczna i sport. Jednak stwierdzić należy, iż kultura fizyczna była sformułowaniem dominującym jeżeli chodzi o użycie ${ }^{23}$.

21 J. Kosiewicz, Sport w perspektywie..., op. cit., s. 11.

22 P. Godlewski, Nauki o kulturze fizycznej - proces autonomizacji i rozwoju (bardziej o społecznych i humanistycznych grupach tematycznych), [w:] Kultura fizyczna $w$ Polsce Ludowej i Trzeciej Rzeczypospolitej, L. Nowak, P. Pieczyński, R. Urban (red.), Gorzów Wielkopolski 2012, s. 30.

23 Por.: M. Segał, Święta kultury fizycznej, Warszawa 1951, s. 9; K. W. Jankowski, J. Kosiewicz, S. Wanat, J. Żyśko, Przeobrażenia systemowo-strukturalne kultury fizycznej, [w:] Przeobrażenia kultury fizycznej w krajach Europy Środkowej i Wschodniej, K. W. Jankowski, Z. Krawczyk (red.), Warszawa 1997, s. 123. 
Od drugiej połowy lat czterdziestych w Polsce, a także innych krajach socjalistycznych, wprowadzano ukształtowany w Związku Radzieckim model kultury fizycznej. Miała ona na celu wspomaganie psychofizycznej przebudowy społeczeństwa oraz stanowienie części nadbudowy społeczeństwa socjalistycznego. Ową służebną rolę kultury fizycznej wobec socjalizmu podkreślano z resztą przez cały okres istnienia Polskiej Rzeczpospolitej Ludowej24. W 1948 roku, a więc 3 lata po zakończeniu wojny, w uchwale Komitetu Centralnego Wszechzwiązkowej Komunistycznej Partii Bolszewików kulturę fizyczną określono jako jeden z najważniejszych środków wychowania komunistycznego, wzmocnienia zdrowia i sił pracujacych mas oraz przygotowania ich do bardziej wydajnej pracy i obrony socjalistycznej ojczy$z n y^{25}$. Zgodnie z dyrektywami komunistycznymi kultura fizyczna posiadała znaczenie rangi państwowej jako część „nowej socjalistycznej kultury". Do jej celów zaliczano masowe uczestnictwo w wychowaniu fizycznym i sporcie, propagując wychowanie w duchu kolektywnym ${ }^{26}$.

Rozwiązania radzieckie, jak wspomniano, były transmitowane do państw satelickich, w tym do Polski. Najpierw w lutym 1948 roku uchwalono w PRL ustawę „O powszechnym obowiązku przysposobienia zawodowego, wychowania fizycznego i przysposobienia wojskowego młodzieży oraz o organizacji spraw kultury fizycznej i sportu", następnie we wrześniu 1949 roku Biuro Polityczne Komitetu Centralnego PZPR przyjęło uchwałę, aby ostatecznie usankcjonować kształt kultury fizycznej w Polsce ustawą z grudnia 1949 roku „o organizacji spraw kultury fizycznej i sportu"27. Wówczas właśnie wprowadzono w PRL nie tylko system organizacji kultury fizycznej zaczerpnięty z ZSRR, ale także skopiowano radzieckie wzorce odnośnie nazewnictwa, o czym pisano już wcześniej.

24 P. Godlewski, Nauki o kulturze..., op. cit., s. 13-14, 16.

${ }^{25}$ Sport w ZSRR, Biuro Propagandy i Agitacji GKKF, Warszawa 1954, s. 8.

${ }^{26}$ A. Zagórska, A. Nowakowski, Ustawa o kulturze fizycznej w Polsce z 1949 roku, [w:] Z najnowszych dziejów kultury fizycznej w Polsce (1918-1989), B. Maksimowska, A. Nowakowski, S. Podobiński (red.), Częstochowa 1999, s. 79.

27 Ibidem, s. 74-75. 
Michał Marcin Kobierecki - Kultura fizyczna a kultura...

W związku z powyższym pojęcie kultury fizycznej określane jest niekiedy jako spuścizna czasów stalinizmu i sowietyzacji Polski. Zdaniem Dobiesława Dudka pogląd taki jest błędny, ponieważ termin w Polsce ma swój rodowód w czasach zaborów i II Rzeczpospolitej. Według D. Dudka terminu zaczęto używać w XIX wieku28. Podobną opinię zaprezentował Jerzy Kosiewicz, według którego termin kultura fizyczna zaczął być w Polsce używany już w okresie przedwojennym. Niektórzy przypisują jego upowszechnienie Józefowi Piłsudskiemu, sam termin zaś miał zostać wyeksponowany w sensie teoretycznym i praktycznym przez czasopismo „Wychowanie Fizyczne”, ukazujące się od 1937 roku. Po II wojnie światowej termin miał zostać nasycony właściwościami ideologicznymi mającymi na celu umocnienie władzy socjalistycznej ${ }^{29}$.

Stwierdzić należy zatem, iż mimo że wiązanie terminu kultura fizyczna z okresem komunizmu nie wydaje się być słuszne w sensie genetycznym, to jednak właśnie wówczas jego stosowanie stało się powszechniejsze. Mimo silnego ideologicznego wykorzystywania kultury fizycznej w okresie rządów komunistycznych nie wydaje się jednak słuszne postrzeganie tego pojęcia w sposób pejoratywny, a tak się niekiedy dzieje. Termin ten nie jest bowiem wymysłem ideologów komunistycznych, a został przez nich jedynie wykorzystany. Dodać przy tym należy, iż kultura fizyczna była czasach PRL rozumiana nieco odmiennie od jej obecnego znaczenia, co można zaobserwować chociażby w szczególnie często pojawiającej się wówczas konstrukcji słownej kultura fizyczna i sport.

28 D. Dudek, Pojęcie kultury fizycznej w polskiej tradycji terminologicznej do 1939 roku, [w:] Z najnowszych dziejów kultury fizycznej i turystyki w Polsce. Dzieje kultury fizycznej i turystyki w Polsce w końcu XIX i XX wieku, t. 1, T. Drozdek-Małolepsza (red.), Częstochowa 2011, s. 9, 14-15, 27.

29 J. Kosiewicz, Sport w perspektywie..., op. cit., s. 27-28. 


\section{Kultura fizyczna jak część składowa kultury w ogóle}

Zanim dokonany zostanie przegląd różnych stanowisk i koncepcji dotyczących miejsca kultury fizycznej w ramach ogólnej kultury, niezbędne jest określenie czym owa kultura jest. Podobnie jak opisywana wcześniej kultura fizyczna, nie jest to pojęcie jednoznaczne. Dowodem na to jest wielość różnych definicji tego terminu - Alfred Kroeber i Clyde Kluckhohn wyróżnili ich ponad $160^{30}$. Co więcej, według niektórych teoretyków kultury fizycznej, to właśnie z niejasnego znaczenia pojęcia kultura wynikają problemy w objaśnianiu czym jest kultura fizyczna.

\section{0 pojęciu kultura}

W pierwotnym sensie terminem kultura określano sfery ludzkiego bytu ontologicznie odrębne od sfery natury ${ }^{31}$. Kulturę ujmuje się niekiedy także jako synonim cywilizacji, a także jako kolektywny zespót umiejętności i dzieło intelektualne każdego społeczeństwa oraz całościowy sposób życia ludzi32. Pojęcie to tłumaczy się także jako siłę sprawczą, która czyni ludzkie zachowania widocznymi i wyróżnialnymi ${ }^{33}$. Mówiąc o kulturze można mieć na myśli normy, wartości, wierzenia albo symbole. Ujmuje się ją także w znaczeniu kultury wysokiej (ujęcie humanistyczne), bądź też jako całościowy sposób życia danego społeczeństwa (ujęcie nauk społecznych). Zgodnie z tym ostatnim

30 S. Bednarek, Kultura jako przedmiot poznania. O statusie kulturoznawstwa jako odrębnej dyscypliny naukowej, [w:] O naturze i kulturze, J. Mozrzymas (red.), Wrocław 2005, s. 11; por. A. Kroeber, C. Kluckhohn, Culture. A Critical Review of Concepts and Definitions, Cambridge 1952.

${ }^{31}$ Kulturę tradycyjnie odróżnia się od sfery zjawisk przynależnych naturze, mimo że podział na rzeczywistość kulturową i naturalną może sprawiać wrażenie abstrakcyjnego. Z. Krawczyk, Kultura globalna a kultura fizyczna, [w:] Socjologia kultury fizycznej, Z. Dziubiński i Z. Krawczyk (red.), Warszawa 2011, s. 67.

${ }^{32}$ C. Jenks, Kultura, Poznań 1999, s. 16-17, 20.

${ }^{33}$ F. Inglis, Kultura, Warszawa 2007, s. 16. 
Michał Marcin Kobierecki - Kultura fizyczna a kultura...

sposobem rozumowania, nie powinno się mówić o kulturze, ale o kulturach $^{34}$.

Jedną z definicji kultury zaprezentował Bronisław Malinowski, według którego jest to aparat instrumentalny, stawiający człowieka $w$ położeniu, w którym lepiej radzi on sobie z konkretnymi, specyficznymi problemami stojącymi przed nim w jego środowisku, $w$ procesie zaspokajania swoich potrzeb ${ }^{35}$. Podobne ujęcie przedstawił Stefan Czarnowski, według którego kulturą określa się dobro zbiorowe i zbiorowy dorobek, owoc twórczego i przetwórczego wysitku niezliczonych pokoleń, przy czym wszelkie odkrycia i wynalazki aby stać się kulturą muszą zostać zachowane dla kolejnych pokoleń ${ }^{36}$. Antonina Kłoskowska, jeden z największych polskich autorytetów zajmujących się badaniami nad kulturą, dokonała przeglądu całego szeregu rozumień pojęcia „kultura” prezentowanych przez przedstawicieli różnych orientacji, stwierdzając przy tym, iż wszystkie zjawiska kultury odnoszq się do człowieka jako uczestnika stosunków społecznych i wszystkie w jakimś zakresie sq wspólne zbiorowościom, grupom i kategoriom społecznym ${ }^{37}$.

Biorąc pod uwagę wielość definicji kultury, nie może dziwić, iż termin ten występuje także $\mathrm{w}$ różnych zakresach znaczeniowych może obejmować dzieła Szekspira, ale także popularne komiksy, operę, futbol amerykański, kwestię kto zmywa naczynia w domu, strukturę urzędu prezydenta USA. Za brytyjskim kulturoznawcą Raymondem Williamsem można wyliczyć kulturę w znaczeniu sztuka i działalność artystyczna, wysublimowane, najczęściej symboliczne cechy określonego sposobu życia oraz pewien proces rozwojowy. Wydaje się jednak, iż obecnie raczej dominuje postrzeganie kultury w znaczeniu szerokim ${ }^{38}$.

34 W. Griswold, Socjologia kultury. Kultury i społeczeństwa $w$ zmieniajacym się świecie, Warszawa 2013, s. 33, 37-38.

${ }^{35}$ S. Jedynak, Kategorie kultury, Lublin 2011, s. 10.

36 S. Czarnowski, Kultura, Warszawa 2005, s. 9.

37 A. Kłoskowska, Socjologia kultury, Warszawa 2007, s. 30.

${ }^{38}$ E. Baldwin, B. Longhurst, S. McCracken, M. Ogborn I G. Smith, Wstęp do kulturoznawstwa, Poznań 2004, s. 24-27. 
Warto wspomnieć także o podziałach terminu kultura. Teoretycy dzielą ją na szereg sposobów, jednak w pracach naukowych najczęściej można napotkać podział na kulturę materialną, która dotyczy aktywności materialno-produkcyjnej człowieka i jej produktów oraz duchową, która z kolei obejmuje sferę ludzkiego ducha i jej produktów: nauki, sztuki, literatury, religii, wychowania, polityki. Trudno jednak wskazać fragmenty rzeczywistości, które można by zaliczyć wyłącznie do kultury duchowej bądź materialnej39.

Jak widać, kultura należy do pojęć trudnych czy wręcz niemożliwych do precyzyjnego zdefiniowania i wytłumaczenia. Owa niejasność dotycząca znaczenia kultury zdaniem Zygmunta Baumana wynika nie tylko z wielości definicji, ale także z nieprzystawalności tradycji intelektualnych, które na skutek rozmaitych uwarunkowań historycznych zbiegły się $w$ tym pojęciu ${ }^{40}$. Sytuacja ta sprawia, iż niezwykle trudne może się okazać rozstrzygnięcie co do przynależności kultury fizycznej do kultury w ogóle - biorąc pod uwagę brak zgody co do znaczenia któregokolwiek z tych pojęć.

\section{Miejsce kultury fizycznej w kulturze}

Rozważając miejsce kultury fizycznej w kulturze niezbędne jest przyjrzenie się najbardziej charakterystycznym stanowiskom $\mathrm{w}$ tej kwestii. Mimo że obecnie wydaje się, iż większość znawców tematyki opowiada się ze uznaniem kultury fizycznej za część kultury, w przeszłości wydawały się dominować stanowiska odwrotne ${ }^{41}$. Na problem ten zwrócił uwagę Maciej Demel, według którego kultura fizyczna najczęściej postrzegana jest jako historyczny proces dostosowywania motoryczności do potrzeb zmieniającego się świata, harmonizowania jej z całokształtem kultury materialnej i duchowej. Jednocześnie jak

\footnotetext{
${ }^{39}$ S. Jedynak, op. cit., s. 12.

40 Z. Bauman, Kultura jako praxis, Warszawa 2012, s. 89.

${ }^{41}$ Z. Krawczyk, Natura, kultura - sport. Kontrowersje teoretyczne w Polsce, Warszawa 1970, s. 24.
} 
Michał Marcin Kobierecki - Kultura fizyczna a kultura...

stwierdził ten autor, kultura fizyczna mimo wielu umizgów nie może się wprosić do kultury ogólnej42.

Poglądy o rozdziale pomiędzy kulturą fizyczną a kulturą wynikały częściowo ze studium H. Steinitzera Sport und Kultur, w którym autor ów głosił tezę, iż sport, a zatem jeden z kluczowych elementów kultury fizycznej, działa w sposób destruktywny na kulturę. Jak twierdzono, współzawodnictwo powoduje niezdrową ambicję; egotyczne postawy sportowców nie wpływają na rozwój kultury duchowej i materialnej43. Należy w tym miejscu zwrócić uwagę, iż w stanowisku tym dostrzec można w szczególności kontestowanie udziału sportu w kulturze, nie zaś kultury fizycznej rozumianej jako całość. W dawniejszych latach pojawiały się jednak także opinie, zgodnie z którymi kultura fizyczna powinna być rozpatrywana w związku z kulturą. I tak Florian Znaniecki w odniesieniu do nauki wyróżniał nauki o kulturze fizycznej spośród nauk o kulturze, a także twierdził, iż wartość ciała jest dla podmiotu działającego przedmiotem jego zmiany, a owa wartość wchodzi do jego doświadczenia jako fakt kulturowy ${ }^{44}$.

Tymczasem w ostatnich latach w zdecydowanej większości wydają się być teoretycy kultury fizycznej uznający ją za część kultury. Taki właśnie zapis widnieje także w polskiej Ustawie o kulturze fizycznej z 1996 roku, zgodnie z którą kultura fizyczna jest częściq kultury narodowej ${ }^{45}$. I tak Stanisław Kowalczyk stwierdził, iż tak jak sport jest częścią kultury fizycznej, tak kultura fizyczna stanowi element ogólnej kultury, będąc jej integralnym elementem. Aktywności obejmowane przez kulturę co prawda bezpośrednio dotyczą aktywizacji ludzkiego ciała, jednak są to aktywności całej osobowości człowieka - ciała i ducha. S. Kowalczyk postulował zatem, aby sport (jako jeden z najważ-

42 M. Demel, Szkice krytyczne o kulturze fizycznej, Kraków 1998, s. 10.

${ }^{43}$ D. Dudek, Pojęcie kultury fizycznej..., op. cit., s. 20.

${ }^{44}$ F. Znaniecki, Nauki o kulturze, Warszawa 1992, s. 302, [za:] A. Pawłucki, Nauki o kulturze fizycznej, [w:] Kultura fizyczna i sport $w$ zwierciadle nauk społecznych, W. J. Cynarski, J. Kosiewicz, K. Obodyński (red.), Rzeszów 2012, s. 351.

45 Ustawa o kulturze fizycznej..., op. cit. 
niejszych elementów kultury fizycznej) eksplikowany był w kontekście personalistycznie rozumianej kultury - $w$ tym także kultury fizycznej46.

Podobną opinię zaprezentował Jerzy Świercz, według którego kultura fizyczna stanowi integralnq część kultury i stanowi dorobek, jaki stworzył człowiek we wszystkich dziedzinach życia, na przestrzeni wiekó $w^{47}$. Kulturę fizyczną jako element szerszej kultury dostrzegła także Teresa Żukowska, uznającą ją za część składową kultury globalnej48, a także Piotr Godlewski, według którego kultura fizyczna jest zapewne jednym ze składników kultury ogólnoludzkiej, rozumianej jako całokształt dóbr, a także wartości duchowych i materialnych, będq̨cych wytworem członków społeczeństw w rezultacie ich zbiorowej działalności. Jest zatem częścią kultury analogicznie jak kultura języka, kultura polityczna itp ${ }^{49}$.

Kulturę fizyczną jako specyficzną dziedzinę kultury opisywał także Zbigniew Krawczyk, według którego przejawy kultury fizycznej można ujmować jako uczestnictwo w kulturze. Aktywność ruchowa jest bowiem instrumentem osiągania innych, pozacielesnych wartości. Zatem zdaniem Z. Krawczyka kultura fizyczna funkcjonuje nie tylko jako element zaspokajania potrzeb pierwotnych człowieka, ale także w sferze wartości wtórnych wpływających na sposób i styl życia człowieka. Dotyczy to w szczególności sportu wyczynowego, który często był krytykowany jako element kultury masowej, podczas gdy powinno się go zaliczać do kultury symbolicznej w związku z licznymi znakami towarzyszącymi widowiskom sportowym, jak hymny, flagi, em-

${ }^{46}$ S. Kowalczyk, Sport w świetle personalistycznej koncepcji kultury, [w:] Sport jako kulturowa rzeczywistość, S. Kowalczyk (red.), Warszawa 2005, s. 54, 56.

47 J. Świercz, Historia kultury fizycznej. Fakty i ciekawostki, Brzeście 2005, s. 7.

48 Z. Żukowska, Inspiracje humanistyczne dla rozwoju nauk o kulturze fizycznej, [w:] Wkład nauk humanistycznych do wiedzy o kulturze fizycznej. Szkice z pedagogiki kultury fizycznej, J. Nowocień (red.), t. II, Warszawa 2003, s. 11.

49 P. Godlewski, Współczesne heterogeniczne oblicze sportu - refleksja terminologiczna i metodologiczna, [w:] Wkład nauk humanistycznych do wiedzy o kulturze fizycznej. Historia kultury fizycznej, T. Rychta, J. Chełmecki (red.), t. I, Warszawa 2003, s. 46. 
Michał Marcin Kobierecki - Kultura fizyczna a kultura...

blematy. Symboliczne znaczenia można dostrzec także w zachowaniach samych sportowców ${ }^{50}$.

Do symboli związanych z kulturą fizyczną, chociaż w nieco inny sposób, nawiązał także Jakub Mosz, według którego przedmioty związane ze światem sportu stają się częścią materialnego dziedzictwa kulturowego i służą nabywania kulturowego kapitału. Chodzi tu w szczególności o narzędzia rywalizacji, sportowe ubiory, pamiątki czy przedmioty kolekcjonowania. Przechowują one pamięć o zdarzeniach i gwiazdach sportu ${ }^{51}$. Ten sam autor w innym dziele zwrócił uwagę na fakt, iż sportowe zdarzenia, a zatem istotny element kultury fizycznej, może być rozpatrywany jako zjawisko kulturowe ${ }^{52}$.

Zaliczanie kultury fizycznej do ogólnej kultury postulował także Fred Gras, według którego kultura fizyczna i sport są elementami kultury społecznie determinowanym przez specyficzne cele sprawności fizycznej. Czynią one bowiem człowieka zdolnym do udziału we wszystkich dziedzinach życia. Gras stwierdził ponadto, iż kultura fizyczna jest integralnym aspektem kultury intelektualnej53, a także, iż kontakty między ludźmi związane z kulturą fizyczną, takie jak aktywne uczestnictwo w sporcie czy kibicowanie, są kulturalnymi formami życia społecznego ${ }^{54}$.

Opinię, iż kultura fizyczna należy do kultury w ogóle prezentował także Andrzej Pawłucki, według którego mimo że jest ona systemem społecznym samym w sobie, afirmującym wartość ciała jako dobro

50 Z. Krawczyk, O kulturze fizycznej..., op. cit., s. 21-22, Idem, Kultura fizyczna, [w:] Kultura Fizyczna. Sport. Encyklopedia Kultury Polskiej XX wieku, Z. Krawczyk (red.), Warszawa 1997, s. 11.

${ }^{51} \mathrm{~J}$. Mosz, Kulturowy status rzeczy w globalnym świecie sportu, [w:] Kultura fizyczna a globalizacja, Z. Dziubiński, P. Rymarczyk (red.), Warszawa 2010, s. 99.

52 J. Mosz, Sportowe zdarzenie jako widowisko kulturowe, [w:] Nauki społeczne wobec sportu i kultury fizycznej, J. Kosiewicz, T. Michaluk, K. Pezdek (red.), Wrocław 2013, s. 79.

${ }^{53} \mathrm{~F}$. Gras, Kultura fizyczna i sport jako komponenty kultury i sposobu życia w świetle analizy socjologicznej, [w:] Kulturowe wartości sportu. Materiały VI Międzynarodowego Sympozjum Socjologii Sportu, Cz. I, Z. Krawczyk (red.), Warszawa 1981, s. 170171.

54 Ibidem, s. 172. 
pożądane, to istnieje $\mathrm{w}$ zintegrowaniu $\mathrm{z}$ systemami uczestnictwa w kulturze ${ }^{55}$. Ów autor stwierdził ponadto, iż z punktu widzenia antropologicznego antynaturalizmu, trzeba się uczyć uczestnictwa w życiu kulturowym. Wychowanie do wartości ciała jest więc systemem społecznym, w którym nabywa się kulturowości stosownie do zakresu internalizacji wartości ciała ${ }^{56}$.

Zwolennikiem opcji zakładającej, iż kultura fizyczna jest częścią kultury jest także Bogdan Kunicki. Jak argumentował ów autor, kultura fizyczna często rozpatrywana jest przez naukowców w kategoriach wartości. Analizuje się wówczas chociażby jej autoteliczność bądź też instrumentalny charakter. Interpretacja kultury fizycznej w kategoriach wartości dowodzi zaś, iż stanowi ona niezbywalną część ogólnoludzkiej kultury57. B. Kunicki stwierdził ponadto, iż kultura fizyczna może być postrzegana także jako element kultury symbolicznej - w powiązaniu ze sztuką. Sport, który umożliwia ekspozycję ludzkiej doskonałości był bowiem od dawna źródłem inspiracji artystycznej - w starożytnej Grecji sportowcy obok bogów byli najczęstszym przedmiotem uwieczniania przez artystów ${ }^{58}$.

Jak widać z krótkiej prezentacji stanowisk w badanej materii, nie brakuje zwolenników tezy, iż kultura fizyczna jest częścią kultury. Obecne są również jednak opinie przeciwne. Pojawia się w związku z tym pytanie, z czego wynika brak zgody odnośnie tak fundamentalnego zagadnienia?

Można podjąć próbę odpowiedzi na powyższe pytanie w odniesieniu do różnych sposobów rozumienia pojęcia kultura fizyczna. I tak Zbigniew Krawczyk wymienił w jednym ze swoich dzieł szereg jego ujęć:

${ }^{55}$ A. Pawłucki, Nauki o kulturze fizycznej, Wrocław 2013, s. 16.

56 A. Pawłucki, Nauki o kulturze fizycznej, [w:] Kultura fizyczna i sport..., op. cit., s. 350 .

57 B. J. Kunicki, Społeczeństwo, kultura..., op. cit., s. 62-63.

58 Ibidem, s. 64-65. 
Michał Marcin Kobierecki - Kultura fizyczna a kultura...

- jako całokształt materialnego środowiska, kształtowanego przez człowieka zgodnie z jego możliwościami, potrzebami i wartościami. Według Z. Krawczyka w tym określeniu mieści się zarówno kultura duchowa, jak i materialna.

- jako system wartości, działań oraz ich efektów w dziedzinie cielesnej aktywności człowieka zależnych od zewnętrznych warunków i stymulowanych przez społeczne potrzeby.

- jako zespół form aktywności ruchowej człowieka, podejmowanych świadomie i celowo dla pomnażania urody człowieka, podporządkowanych wzorowi osobowości wszechstronnej, harmonijnej i dynamicznej.

- jako synonim sportu, chociaż jest to ujęcie spotykane bardzo rzadko i tylko w krajach Europy Środkowej i Wschodniej ${ }^{59}$.

Powyższe ujęcia skupiają się na różnych elementach i zdają się obejmować nieco inne zakresy. Z perspektywy niniejszych rozważań z pewnością najbardziej adekwatne wydaje się pierwsze z przytoczonych ujęć, które jest niekiedy określane jako „globalne”. Ich różnorodność może natomiast tłumaczyć po części pewną niejednorodność jeśli chodzi o zaliczanie przez naukowców, lub nie, kultury fizycznej do kategorii ogólnej kultury.

Cytowany powyżej Z. Krawczyk jest autorem szeregu rozważań odnośnie miejsca kultury fizycznej w kulturze. Jego zdaniem rozumując kulturę w ujęciu antropologicznym, wyróżnić można jej trzy sfery: kulturę bytu, kulturę społeczną oraz kulturę symboliczną, przy czym kultura fizyczna nie mieści się całkowicie w żadnej z nich, wręcz przeciwnie - może być stosowana w każdej z nich. Zdaniem Z. Krawczyka najbardziej ugruntowane miejsce kultura fizyczna ma w ramach kultury bytu, związanej $\mathrm{z}$ zaspokajaniem elementarnych potrzeb człowieka, ponieważ czynności takie wymagają odpowiedniej kondycji fizycznej. Tymczasem kultura społeczna obejmuje normy, reguły

59 Z. Krawczyk, Kultura fizyczna, s. 11-12; Idem, Teoretyczne orientacje $w$ socjologii kultury fizycznej, [w:] Socjologia kultury fizycznej, Z. Dziubiński i Z. Krawczyk (red.), Warszawa 2011, s. 39-40. 
i standardy zachowań oraz role społeczne. Ma to związek z procesami interakcyjnymi i integracyjnymi. Właśnie takie procesy związane są także z uczestnictwem w kulturze fizycznej, np. prestiż osiągnięty w zabawie ruchowej czy w sporcie u dzieci przekłada się często na pozycję w grupie. Autor ów za nieco trudniejsze uznał umiejscowienie kultury fizycznej w sferze kultury symbolicznej60, jednak jak wynika z wcześniej przytoczonych rozważań, zagadnienia związane z kulturą fizyczna noszą także znaczenie symboliczne.

Zbliżoną opinię zaprezentowali Bogdan Czabański i Czesław Makutynowicz. Autorzy ci nawiązali jednak do innego podziału kultury: na materialną (rezultat przekształcania przyrody przez człowieka) i duchową (efekt przekształcania się samego człowieka w toku opanowywania przyrody). Ich zdaniem kultura fizyczna, będąca jednocześnie swoistą formą kultury, nie mieści się w całości w żadnym z jej rodzajów, a jej odrębność w odniesieniu do innych sfer kultury polega przede wszystkim na odmienności jej podłoża, ale także środków i rezultatów. Chodzi tu o szczególne narzędzie - wyabstrahowany od użytkowej celowości ruch ciała61.

Podobną opinię zaprezentował Andrzej Wohl, którego zdaniem badania cywilizacji pierwotnych wskazują, iż już w elementarnych fazach rozwoju społecznego pojawiły się czynności, które należałoby określić jako ćwiczenia fizyczne. Co więcej, najbardziej pierwotna kultura w znacznym stopniu była kulturą polegającą na doskonaleniu ciała, obejmującą chociażby tatuaże, ceremoniały taneczne i zabawowo-ruchowe, próby wytrzymałości fizycznej czy regularne ćwiczenia. Wytworzony historycznie w ten sposób dorobek ludzkości w dziedzinie pielęgnacji ciała i rozwoju fizycznego stanowi nieodłączną część kultury. Jednak zdaniem A. Wohla składowe kultury fizycznej wymykają się poza zarówno sferę kultury materialnej, jak i duchowej. Co

60 Z. Krawczyk, Kultura fizyczna, s. 15-17, Idem, Kultura globalna.., op. cit., s. 6971.

61 B. Czabański, C. Makutynowicz, Teoria wychowania fizycznego z elementami teorii sportu, Zielona Góra 1996, s. 9-10. 
Michał Marcin Kobierecki - Kultura fizyczna a kultura...

prawda sprzęt sportowy można by zaliczyć do kultury materialnej, wiedzę w tym zakresie zaś do kultury duchowej, jednak zabiegi służące do pielęgnacji ciała, charakter widowisk sportowych czy wzory zachowań ukształtowane przez sport nie mieszczą się w żadnej z tych kategorii. A. Wohl stwierdził zatem, iż obok kultury materialnej i duchowej należałoby wskazać kulturę fizyczną jako swoistą trzecią stronę kultury, zaś jej istotę stanowi przystosowanie rozwoju fizycznego ludzi do procesów wynikających z dwóch pozostałych jej stron ${ }^{62}$. Co do tej opinii Andrzeja Wohla można mieć jednak pewne wątpliwości. 0 ile słuszne wydaje się stanowisko Bogdana Czabańskiego i Czesława Makutynowicza na temat swoistości kultury fizycznej jako elementu kultury, to trudno się zgodzić ze stwierdzeniem, iż należałoby ją rozpatrywać jako trzecią sferę kultury, obok duchowej i materialnej.

Istnieje ponadto szereg rozważań poświęconych sportowi i jego związków z kulturą. Jest on niekiedy interpretowany jako specyficzny rodzaj gry, która z kolei zaliczana jest do dziedziny zabawy. Tymczasem trudno kwestionować wpływ zabawy na kształtowanie kultury. Trzeba jednak zauważyć, iż obecny sport coraz silniej odchodzi od oryginalnego dla siebie zabawowego wymiaru. Szczególnie w formie wyczynowej sport współczesny stał się bowiem instrumentem osiągania innych niż autoteliczne wartości. Jak wynika z przytoczonych wcześniej stanowisk, sport był pod tym względem krytykowany w związku z ewentualnym destrukcyjnym wpływem na kulturę. Obecnie jednak głoszone są opinie, iż sport może być w znaczącym stopniu elementem kultury masowej. Dotyczy to w szczególności sportu zawodowego, jak stwierdził Zbigniew Krawczyk ${ }^{63}$.

Kultura masowa to kultura rozpowszechniana za pomocą technicznych środków masowego przekazu, takich jak radio, telewizja czy

62 A. Wohl, Pojęcie kultury fizycznej, [w:] Kultura fizyczna i sport $w$ ujęciu socjologicznym. Wybór tekstów, H. Sekuła-Kwaśniewicz (red.), Kraków 1985, s. 24-27.

63 Z. Krawczyk, Sport i kultura, s. 18-19; J. Mosz, Sport w kontekście wartości estetycznych, [w:] Aksjologia sportu, Z. Dziubiński (red.), Warszawa 2001, s. 106. 
gazety. Jej cechą charakterystyczną jest to, że z niewielkiej liczby źródeł płynie do wielkich mas odbiorców. Od swojego zarania była ona silnie krytykowana. Sport - jeden z segmentów kultury fizycznej, zaliczany jest często właśnie do kultury masowej64. Traktowany jest nie tylko jako jej element, ale i wytwór. Dzieje się tak za sprawą jego wielkiej popularności. Ulega bowiem komercjalizacji oraz utowarowieniu, a produktami w świecie sportu są zdarzenia sportowe, relacje ze sportowych zdarzeń, drużyny sportowe i sami sportowcy, a w sytuacjach patologicznych także sama rywalizacja65. Trudno nie zgodzić się z tym stanowiskiem. Wielka popularność sportu sprawiła, że naturalnym jest zaliczanie go do spectrum kultury masowej, a świadczą o tym chociażby liczby widzów śledzących wydarzenia sportowe na ekranach telewizorów, sięgające wielu milionów. Za nieco kontrowersyjne można uznać stanowisko, iż sport jest wytworem kultury masowej. Sport rozwijał się bowiem wcześniej. Stwierdzić jednak przy tym trzeba, iż z pewnością kultura masowa wpłynęła na kształt współczesnego sportu elitarnego.

\section{Konkluzje}

Rozważaniom dotyczącym kultury towarzyszy nierzadko refleksja dotycząca jej ujęć z określonym przymiotnikiem. Stąd też mówi się np. o kulturze artystycznej, kulturze społecznej, kulturze politycznej i kulturze historycznej. Traktowanie kultury fizycznej jako segmentu kultury wydaje się w związku z tym czymś naturalnym, jednak jak wynika z powyższych rozważań, nie zawsze jest ona w ten sposób postrzegana.

Źródła problemu dotyczącego zaliczenia kultury fizycznej bądź nie do kultury wydają się być oczywiste, mianowicie wynikają z niejasności terminologicznej żadnego z tych dwóch pojęć. W przypadku kultu-

64 P. Rymarczyk, Kultura masowa i kultura fizyczna, [w:] Socjologia kultury fizycznej, Z. Dziubiński i Z. Krawczyk (red.), Warszawa 2011, s. 84, 86-87.

65 J. Mosz, Kulturowy status rzeczy..., op. cit., s. 89-90, 98. 
Michał Marcin Kobierecki - Kultura fizyczna a kultura...

ry wynikają one najpewniej z różnych tradycji naukowych, jakie reprezentują jej teoretycy, tymczasem nieścisłość terminologiczna kultury fizycznej wynika zapewne z niejednolitego postrzegania zakresu tej kategorii, chociaż jak się zdaje, co do trzonu tego pojęcia panuje względna zgoda. Decyzja, czy niejednoznaczną kategorię należy zaliczyć do innej, równie niejednoznacznej kategorii, może być w związku $\mathrm{z}$ tym trudna.

Pomimo opisanych wyżej nieścisłości terminologicznych wydaje się, iż znaczenie obu terminów jest zrozumiałe, rozbieżności zaś wynikają przede wszystkim z zakresu danego pojęcia przyjętego przez danego teoretyka - węższego bądź szerszego. Przegląd charakterystycznych stanowisk karze sądzić, iż większość naukowców przychyla się obecnie raczej do postrzegania przede wszystkim kultury w sposób szerszy, integrujący cały niemal dorobek ludzkości. Postrzeganie kulturę w ten sposób nasuwa wniosek, iż kulturę fizyczną należy zaliczyć do jej zakresu. Nawet postrzegając kulturę fizyczną w sposób najszerszy z możliwych - globalny, każdy z jej komponentów z powodzeniem zasługuje na miano fragmentu ogólnej kultury. Wydarzenie sportowe odbywa się na różnorodnych obiektach przy użyciu mniej lub bardziej specjalistycznego sprzętu sportowego; osoby uprawiające różne dyscypliny sportu czy też rekreację fizyczną zachowują się według wytworzonych przez lata wzorców, czy to dotyczących techniki wykonywania poszczególnych czynności, czy też treningu przygotowującego do wykonywania go. Jeszcze bardziej oczywiste jest miejsce w kulturze wychowania fizycznego, które podobnie jak inne formy wychowania wprowadzają człowieka do kultury. To samo dotyczy turystyki i rehabilitacji fizycznej. Turystyka ma na celu najczęściej odwiedzenie konkretnych miejsc uznanych poniekąd „kulturowo" za interesujące i godne odwiedzenia (tyczy się to zarówno atrakcji turystycznych stworzonych przez człowieka, jak i naturalnych), rehabilitacja zaś uwzględnia wytworzone przez lata i przekazywane sposoby przywracania ludzi do stanu sprzed urazu fizycznego. 
Uwzględniając to zasadnym wydaje się stwierdzenie, iż kultura fizyczna jest elementem ogólnej kultury.

\section{Bibliografia:}

Baldwin E., Longhurst B., McCracken S., Ogborn M., Smith G., Wstęp do kulturoznawstwa, Poznań 2004.

Bauman Z., Kultura jako praxis, Warszawa 2012.

Bednarek S., Kultura jako przedmiot poznania. O statusie kulturoznawstwa jako odrębnej dyscypliny naukowej, [w:] O naturze i kulturze, J. Mozrzymas (red.), Wrocław 2005.

Czabański B., Makutynowicz C., Teoria wychowania fizycznego z elementami teorii sportu, Zielona Góra 1996.

Czarnowski S., Kultura, Warszawa 2005.

Demel M., Szkice krytyczne o kulturze fizycznej, Kraków 1998.

Dudek D., Pojęcie kultury fizycznej w polskiej tradycji terminologicznej do 1939 roku, [w:] Z najnowszych dziejów kultury fizycznej i turystyki w Polsce. Dzieje kultury fizycznej i turystyki w Polsce w końcu XIX i XX wieku, t. 1, T. Drozdek-Małolepsza (red.), Częstochowa 2011.

Eichberg H., Body Culture. Essays on sport, space and identity, J. Bale, C. Philo (red.), London 1998.

Godlewski P., Nauki o kulturze fizycznej - proces autonomizacji i rozwoju (bardziej o społecznych i humanistycznych grupach tematycznych), [w:] Kultura fizyczna w Polsce Ludowej i Trzeciej Rzeczypospolitej, L. Nowak, P. Pieczyński, R. Urban (red.), Gorzów Wielkopolski 2012.

Godlewski P., Współczesne heterogeniczne oblicze sportu - refleksja terminologiczna i metodologiczna, [w:] Wkład nauk humanistycznych do wiedzy o kulturze fizycznej. Historia kultury fizycznej, T. Rychta, J. Chełmecki (red.), t. I, Warszawa 2003.

Grabowski H., Wychowanie fizyczne, [w:] Kultura fizyczna. Sport. Encyklopedia kultury polskiej XX wieku, Z. Krawczyk (red.), Warszawa 1997.

Gras F., Kultura fizyczna i sport jako komponenty kultury i sposobu życia w świetle analizy socjologicznej, [w:] Kulturowe wartości sportu. Materiały VI Międzynarodowego Sympozjum Socjologii Sportu, Cz. I, Z. Krawczyk (red.), Warszawa 1981. 
Michał Marcin Kobierecki - Kultura fizyczna a kultura...

Griswold W., Socjologia kultury. Kultury i społeczeństwa w zmieniającym się świecie, Warszawa 2013.

Haywood L. et al., Understanding Leisure, Cheltenham 2002.

Inglis F., Kultura, Warszawa 2007.

Jankowski K. W., Kosiewicz J., Wanat S., Żyśko J., Przeobrażenia systemowostrukturalne kultury fizycznej, [w:] Przeobrażenia kultury fizycznej w krajach Europy Środkowej i Wschodniej, K. W. Jankowski, Z. Krawczyk (red.), Warszawa 1997.

Jedynak S., Kategorie kultury, Lublin 2011.

Jenks C., Kultura, Poznań 1999.

Kłoskowska A., Socjologia kultury, Warszawa 2007.

Kobierecki M. M., Czym jest sport? Analiza wybranych definicji pojęcia „sport” oraz pojęć zbliżonych, [w:] Z dziejów kultury fizycznej Polski oraz wybranych regionów i mniejszości narodowych, J. Dżereń (red.), Płock 2011, s. 232.

Kosiewicz J., Free Time and Freedom of Choice, [w:] Movement Recreation for All, J. Kosiewicz (red.), Legionowo 2006.

Kosiewicz J., Kultura fizyczna i sport w perspektywie filozofii, Warszawa 2000.

Kosiewicz J., Sport and Philosophy. From Methodology to Ethics, Warszawa 2009.

Kosiewicz J., Sport w perspektywie filozofii, [w:] Nauki społeczne wobec sportu współczesnego, J. Kosiewicz, P. Bany, M. Piątkowska, J. Żyśko (red.), Warszawa 2010.

Kosiewicz J., Spór o istnienie i wolność wyboru, [w:] Sport jako kulturowa rzeczywistość, Z. Dziubiński (red.), Warszawa 2005.

Kowalczyk S., Sport w świetle personalistycznej koncepcji kultury, [w:] Sport jako kulturowa rzeczywistość, S. Kowalczyk (red.), Warszawa 2005.

Krawczyk Z., Od aksjologii ciała do koncepcji kultury fizycznej, [w:] Kultura fizyczna i sport w ujęciu socjologicznym. Wybór tekstów, H. Sekuła-Kwaśniewicz (red.), Kraków 1985.

Krawczyk Z., Kultura fizyczna, [w:] Kultura Fizyczna. Sport. Encyklopedia Kultury Polskiej XX wieku, Z. Krawczyk (red.), Warszawa 1997.

Krawczyk Z., Kultura globalna a kultura fizyczna, [w:] Socjologia kultury fizycznej, Z. Dziubiński i Z. Krawczyk (red.), Warszawa 2011.

Krawczyk Z., Natura, kultura - sport. Kontrowersje teoretyczne w Polsce, Warszawa 1970.

Krawczyk Z., o kulturze fizycznej. Studia i szkice, Warszawa 1983. 
Krawczyk Z., Teoretyczne orientacje w socjologii kultury fizycznej, [w:] Socjologia kultury fizycznej, Z. Dziubiński i Z. Krawczyk (red.), Warszawa 2011.

Kroeber A., Kluckhohn C., Culture. A Critical Review of Concepts and Definitions, Cambridge 1952.

Kunicki B. J., Społeczeństwo, kultura, kultura fizyczna, [w:] Socjologia kultury fizycznej, Z. Dziubiński, Z. Krawczyk (red.), Warszawa 2011.

Marcinkowski M., Sokołowski M., Aksjologiczne i funkcjonalne aspekty kultury fizycznej w wojsku, t. VII, Warszawa 2004.

Mosz J., Kulturowy status rzeczy w globalnym świecie sportu, [w:] Kultura fizyczna a globalizacja, Z. Dziubiński, P. Rymarczyk (red.), Warszawa 2010.

Mosz J., Sport w kontekście wartości estetycznych, [w:] Aksjologia sportu, Z. Dziubiński (red.), Warszawa 2001.

Mosz J., Sportowe zdarzenie jako widowisko kulturowe, [w:] Nauki społeczne wobec sportu i kultury fizycznej, J. Kosiewicz, T. Michaluk, K. Pezdek (red.), Wrocław 2013.

Nowakowski A., Zarzq̨dzanie kultura fizycznq w Polsce w latach 1944-2001. Studium historyczno-porównawcze, Rzeszów 2005.

Pawłucki A., Nauki o kulturze fizycznej, [w:] Kultura fizyczna i sport $w$ zwierciadle nauk społecznych, W. J. Cynarski, J. Kosiewicz, K. Obodyński (red.), Rzeszów 2012.

Pawłucki A., Nauki o kulturze fizycznej, Wrocław 2013.

Pawłucki A., Naukowa legitymizacja rehabilitacji cielesnej, [w:] „Rozprawy Naukowe Akademii Wychowania Fizycznego we Wrocławiu” 2012, nr 39.

Ryby B., Kultura fizyczna - ważna dziedzina życia społecznego, [w:] Księga sportu polskiego 1944-1974, J. Rajkowska (red.), Warszawa 1975.

Rymarczyk P., Kultura masowa i kultura fizyczna, [w:] Socjologia kultury fizycznej, Z. Dziubiński i Z. Krawczyk (red.), Warszawa 2011.

Segał M., Święta kultury fizycznej, Warszawa 1951.

Sport w ZSRR, Biuro Propagandy i Agitacji GKKF, Warszawa 1954.

Szczechowicz B., Kultura fizyczna jako źródło wartości produktu turystycznego, Warszawa 2012.

Świercz J., Historia kultury fizycznej. Fakty i ciekawostki, Brzeście 2005.

Ustawa o kulturze fizycznej z dnia 18 stycznia 1996 r., Dz. U. Nr 25, poz. 113.

Ustawa z dnia 25 czerwca 2010 o sporcie, Dz. U. z 2010 r. Nr 127, s. 1. 
Michał Marcin Kobierecki - Kultura fizyczna a kultura...

Wohl A., Pojęcie kultury fizycznej, [w:] Kultura fizyczna i sport w ujęciu socjologicznym. Wybór tekstów, H. Sekuła-Kwaśniewicz (red.), Kraków 1985.

Wolańska T., Rekreacja fizyczna, Warszawa 1971.

Zagórska A., Nowakowski A., Ustawa o kulturze fizycznej w Polsce z 1949 roku, [w:] Z najnowszych dziejów kultury fizycznej w Polsce (1918-1989), B. Maksimowska, A. Nowakowski, S. Podobiński (red.), Częstochowa 1999. Znaniecki F., Nauki o kulturze, Warszawa 1992.

Żukowska Z., Inspiracje humanistyczne dla rozwoju nauk o kulturze fizycznej, [w:] Wkład nauk humanistycznych do wiedzy o kulturze fizycznej. Szkice z pedagogiki kultury fizycznej, J. Nowocień (red.), t. II, Warszawa 2003. 